\title{
Acid scarification and hot water soaking of Racosperma auriculiforme seeds
}

\author{
by P.D. Khasa
}

Nine methods of overcoming seed-coat dormancy of Racosperma auriculiforme (provenance KZNO) from Zaïre were investigated. Soaking seeds in concentrated sulphuric acid for 15 or $30 \mathrm{~min}$ and then rinsing for $15 \mathrm{~min}$ with tap water produced the best results for laboratory testing as well as operational application. Boiling water from which the heat source has been removed and in which the seeds are placed and soaked until the water is cool (12-24 h) is the most suitable and economical method for social forestry programs at the village level in Zaïre.

Key words: Acacia, germination, Leguminosae, Racosperma, seed-coat dormancy, social forestry

\section{Introduction}

Racosperma auriculiforme (Cunn. ex Benth.) Pedley (formerly Acacia auriculiformis) belonging to the Leguminosae family (subfamily, Mimosoideae; Tribe, Acacieae) was introduced to Zaïre in 1968 but details of the seed origin remain obscure. This species is indigenous to Australia, Papua New Guinea, Irian Jaya and the Kei Islands of Indonesia (Turnbull 1986).

In Zaïre, rapid population growth and urbanisation are identified as important factors causing the shortage of fuel wood. With 38 million people in $1993,88 \%$ of the total energetic consumption in Zaire is from ligneous origin, of which $99 \%$ is used for the purpose of cooking and heating. Kinshasa (capital of Zaïre) alone needs 300,000 tons of charcoal per year (Zins and Kambale 1989). Similarly, the shortage of fuel wood is spreading in the 14 official cities and the savannah regions of Zaïre.

Because of its outstanding amenity attributes (Jim 1990), planting of $R$. auriculiforme has intensified throughout the country. In rural areas, non-governmental organizations are involved in educating farmers on how to grow their own energy by using promising agroforestry techniques, whereas around towns governmental-managed large-scale plantations for production of fuel wood and charcoal are planned. For example, an industrial tree planting project of 8,000 ha is underway on the Bateke plateau situated approximatively $150 \mathrm{~km} \mathrm{NE}$ from Kinshasa city (lat. $4^{\circ} 22^{\prime} \mathrm{S}$, long. $15^{\circ} 17^{\prime} \mathrm{E}$, mean alt. $300 \mathrm{~m}$ ). This project has been carried out by the HVA-Holland Agro Industries bv, the final goal of which is 100,000 ha of fuel wood plantations to meet the fuel wood demands of Kinshasa city by the year 2,000 (Anon. 1985).

From 1979 to now, one seed production area of about 300 ha was established by the Service National de Reboisement at the Centre Forestier de Kinzono on the Bateke

Centre de recherche en biologie forestière, Faculté de foresterie et de géomatique, Université Laval, Québec, Canada G1K 7 P4.

Département de biologie, Faculté des sciences, B.P. 190, Université de Kinshasa, Zaïre.
En vue de briser la dormance due aux téguments des graines d'Aracosperma auriculiforme (Provenance KZNO) récoltées au Zaïre, neuf méthodes ont été étudiées. Le trempage de graines dans l'acide sulfurique concentré durant 15 ou 30 min, suivi d'un rinçage à l'eau de robinet pendant $15 \mathrm{~min}$, a donné les meilleurs résultats aussi bien pour des tests de germination en laboratoire que pour une application opérationnelle. Le trempage de graines dans l'eau bouillante, retirée de la source de chauffage jusqu'au refroidissement (12-24h) est la méthode la plus appropriée et économique au niveau du village pour des programmes de foresterie sociale au Zaïre.

Mots clés: Acacia, germination, Légumineuses, Racosperma. dormance tégumentaire, foresterie sociale
Plateau (lat. $4^{\circ} 22^{\prime} \mathrm{S}$, long. $16^{\circ} 17^{\prime} \mathrm{E}$, alt. $650 \mathrm{~m}$ ). All seeds required in artificial regeneration programs come from this seed production area.

Seeds of Racosperma spp. are known to have hard seedcoats that completely prevent the imbibition of water and exchange of gas, thus preventing initiation of the germination process (Willan 1985, Marunda 1990). Such physical seed-coat dormancy occurs most frequently in species adapted to alternating dry and wet seasons. To accelerate germination of Racosperma seeds, various pretreatment methods have been assayed including nicking, soaking in hot or boiling water, and sulfuric acid scarification (Doran et al. 1983 . Doran and Gunn 1987, Gunn 1990). Results have varied among Racosperma spp., among seedlots of the same species, and within the same seedlot. The proportion of hardcoated seeds in a sample may be influenced by many factors including the environmental conditions during the growth of the plant, the degree of maturation of the seeds when collected, and duration and type of seed storage (Willan 1985, Pukittayacamee and Hellum 1987). Hence, it is difficult to prescribe an "optimum" treatment (or range of treatments) that is highly effective in stimulating germination in most Racosperma seeds (Doran and Gunn 1987).

In any case, it is important to develop efficient, easilyapplied seed pretreatment methods that can be used either in industrial nurseries for managed, large-scale plantations, or in village nurseries for social forestry. Results of nine treatment methods tested on seeds of unknown origin collected from the only Racosperma auriculiforme seed production area in Zaïre are reported, with recommendations for nursery practice and for social forestry in rural communities.

\section{Materials and Methods}

Seeds were collected in June 1989 from four superior stands at the Centre Forestier de Kinzono situated on the Bateke plateau. The seeds were spread and sun-dried on plastic sheeting during 3 days at the mean temperature of $26^{\circ} \mathrm{C}$ prevailing in June and kept in hermetically sealed polyethylene containers until used in this study in November 
Table 1. Description of seed treatments used in this study

\begin{tabular}{cl}
\hline Treatment & \multicolumn{1}{c}{ Description } \\
\hline 0 & Control (no treatment). \\
1 & Boiling water, immersion for 1 min. \\
2 & As for 1, with 3 min immersion. \\
3 & As for 1, with 5 min immersion. \\
4 & Soak 1 volume of seeds in 10 volumes of boiling water \\
& from which the heat source is removed, until cool (12-24h) \\
5 & Acid $\left(\mathrm{H}_{2} \mathrm{SO}_{4}\right)$ scarification: seeds were immersed in \\
& $95-98 \%(\mathrm{~V} / \mathrm{V})$ concentrated sulfuric acid at room \\
& temperature 15 min, then rinsed under running tap water \\
6 & for 15 min. \\
7 & As for 5, with immersion for 30 min. \\
8 & As for 5, with immersion for 45 min. \\
& As for 5, with immersion for 60 min.
\end{tabular}

1990. Nine treatments were tested (Table 1). Poor quality seeds (insect damaged, empty seeds, immature seeds, shrunken) were removed by water flotation; mature, filled seeds sink. Four replications of 100 seeds each were used for each treatment in a completely randomized design (International Seed Testing Association 1985).

Pretreated seeds were germinated on Kimpak K-22 (cellulose paper, from Kimberly-Clark Corporation, Wisconsin, U.S.A.) in the germination boxes described by Wang and Ackerman (1983). The medium was initially moistened to saturation point with distilled water. Germination was conducted in Conviron G30 germinators (Controlled Environments, Winnipeg, Manitoba) at $16 \mathrm{~h}$ photoperiod, $30-20^{\circ} \mathrm{C}$ temperature regime (day-night), and $85 \%$ relative humidity. Light was supplied from fluorescent bulbs at an intensity of approximately $12 \mu \mathrm{E} \mathrm{m}^{-2} \mathrm{~s}^{-1}$.

Germination counts were made every 2 days up to a maximum of 20 days. Seeds were considered to have germinated when their radicles had reached the same length as the seedcoat. Cumulative germination percentages (CGs) were calculated. Analysis of variance was done using the ANOVA procedure of SAS ${ }^{\circledR}$ (SAS Institute 1990). Comparisons of means among treatments were performed using Tukey's studentized range (HSD) test at alpha $=0.05$. The basic assumptions of normality, homogeneity of variance, additivity of effects and the identity in number of observations in each treatment for using this procedure were respected (Kirk 1982).

\section{Results and Discussion}

For the nursery manager, the best seed pretreatment is that providing rapid, uniform and high germination. The pretreatment best able to attain this goal must be determined in order to give maximum nursery recovery of high quality seedlings.

Of the water pretreatments tested (treatments 1-4), soaking seeds in boiling water (heat source removed) (treatment 4) gave the best germination, $77.5 \%$ (Table 2). Immersing the seeds in boiling water for $1 \mathrm{~min}$ (treatment 1 ) gave the second highest result for water pretreatments, $51.0 \%$. This treatment, incidentally, is the one adopted by the Australian Tree Seed Centre as the recommended standard (Doran and Gunn 1987, Gunn 1990). Immersion of seeds in boiling water may stimulate germination by causing rupture of the lens tissue, thereby allowing water to enter the seeds (Cavanagh 1987). While the control (treatment 0 ) seeds germinated $23.5 \%$, immersion in boiling water for 3 and 5 min (treatments 2 and 3) gave the worst results (Table 2), killing many embryos and encouraging fungal growth.

All acid scarification treatments produced earlier germination and higher CGs than water treatments (Figure 1, Table 2). Scarification in concentrated $\mathrm{H}_{2} \mathrm{SO}_{4}$ 95-98\% ( $\mathrm{vol} / \mathrm{vol}$ ) for $15 \mathrm{~min}$ (treatment 5 ) gave the best germination, $93 \%$, although this was not significantly different from scarification for $30 \mathrm{~min}$ (treatment 6), or immersion in boiling water (treatment 4 ) (Table 2). The similar results obtained with treatments 5 and 6 mean that, if seeds are left slightly longer than $15 \mathrm{~min}$ in $\mathrm{H}_{2} \mathrm{SO}_{4}$, no adverse affect is likely. For application in Zaïre, soaking seeds in concentrated $\mathrm{H}_{2} \mathrm{SO}_{4}(95 \%, 36 \mathrm{~N}$ ) for 30 min (treatment 6) gave rapid, uniform and high germination in a fine sand medium (over 90\%), with seedlings of higher vigour (Khasa, unpublished data). This method has been adopted in an industrial tree planting project on the Bateke Plateau by the HVAHolland Agro Industries bv. As the $\mathrm{H}_{2} \mathrm{SO}_{4}$ used in this study was slightly more concentrated than that used in Zaïre, a shorter acid soak $(15 \mathrm{~min})$ might have been expected to give better results. Since this treatment gave the best germination at 4 days, and remained superior throughout the test (Figure 1, Table 2), delays in seedling emergence are unlikely in the nursery. Duration of acid scarification may be likely extended by diluting the acid or during the re-use of acid in order to reduce cost, but this was not tested. Acid scarification for 45 and 60 min (treatments 7 and 8) caused high seed mortality accompanied by heavy fungal development. However, the same treatments ( 6 and 7$)$ gave the best germination in the first 2 days because of the rapid inflow of water and enhanced gas exchange brought on by the reduction in seedcoat thickness following the longer acid exposure.

Variation among replications was smallest in treatments 5,6 and 4, respectively, indicating that these treatments

Table 2. Cumulative germination percentages of $R$. auriculiforme

\begin{tabular}{ccccccccccc}
\hline & \multicolumn{7}{c}{ Duration of germination test (days) } \\
\cline { 2 - 10 } Treatment & $\mathbf{2}$ & $\mathbf{4}$ & $\mathbf{6}$ & $\mathbf{8}$ & $\mathbf{1 0}$ & $\mathbf{1 2}$ & $\mathbf{1 4}$ & $\mathbf{1 6}$ & $\mathbf{1 8}$ & $\mathbf{2 0}$ \\
\hline & $0.0 c(0.0)$ & $0.1 c(0.10)^{1}$ & $1.0 d(1.0)$ & $2.0 c(1.6)$ & $5.0 e(2.6)$ & $7.0 d(1.2)$ & $10.0 d(2.8)$ & $17.0 c d(3.4)$ & $20.0 f g(4.0)$ & $23.5 c(4.1)$ \\
1 & $0.0 c(0.0)$ & $0.0 c(0.0)$ & $0.0 d(0.0)$ & $3.0 c(2.0)$ & $7.5 e d(1.0)$ & $10.0 d(1.6)$ & $15.0 d(4.0)$ & $28.5 c(5.5)$ & $38.5 e f(6.0)$ & $51.0 b(8.2)$ \\
2 & $0.0 c(0.0)$ & $0.0 c(0.0)$ & $0.0 d(0.0)$ & $0.0 c(0.0)$ & $1.5 e(1.6)$ & $4.0 d(3.9)$ & $7.0 d(3.8)$ & $7.5 d(3.7)$ & $8.5 g(4.4)$ & $12.00 c(6.3)$ \\
3 & $0.0 c(0.0)$ & $0.0 c(0.0)$ & $0.0 d(0.0)$ & $0.0 c(0.0)$ & $0.0 e(0.0)$ & $1.00 d(1.2)$ & $2.5 d(2.5)$ & $3.5 d(3.0)$ & $5.5 g(3.0)$ & $7.0 c(3.4)$ \\
4 & $0.0 c(0.0)$ & $0.1 c(0.10)$ & $2.5 d(2.5)$ & $7.5 c(3.6)$ & $22.0 d(5.0)$ & $30.5 c(5.5)$ & $36.0 c(5.4)$ & $53.0 b(5.0)$ & $60.5 b c d(4.9)$ & $77.5 a(3.8)$ \\
5 & $7.5 b(3.0)$ & $69.5 a(4.4)$ & $80.0 a(2.8)$ & $81.5 a(2.6)$ & $85.0 a(2.0)$ & $85.5 a(1.0)$ & $89.0 a(1.1)$ & $92.0 a(1.3)$ & $92.5 a(1.4)$ & $93.0 a(1.2)$ \\
6 & $22.5 a(3.0)$ & $61.0 a b(5.0)$ & $70.5 a(3.7)$ & $76.5 a(3.4)$ & $78.0 a(3.0)$ & $79.0 a(2.8)$ & $78.0 a(2.6)$ & $78.0 a(2.4)$ & $78.0 a(2.4)$ & $78.0 a(2.4)$ \\
7 & $18.5 a(1.0)$ & $50.5 b(6.3)$ & $56.5 b c(6.8)$ & $60.0 b(7.0)$ & $60.0 b c(6.0)$ & $56.5 b(7.2)$ & $54.0 b(7.7)$ & $56.0 b(7.9)$ & $55.0 c d e(7.6)$ & $55.0 b(7.6)$ \\
8 & $11.0 b(3.5)$ & $49.0 b(6.8)$ & $55.0 c(6.6)$ & $58.0 b(7.5)$ & $56.0 c(8.0)$ & $52.0 b(9.6)$ & $46.0 b c(9.0)$ & $44.5 b(9.5)$ & $44.5 d e(9.5)$ & $44.5 b(9.4)$ \\
\hline
\end{tabular}

$a-g$ Within each column, means followed by the same letter are not significantly different (alpha $=0.05$ ) by Tukey's studentized range (HSD) Test.

${ }^{1}$ Numbers in parentheses are standard deviations (SDs). 


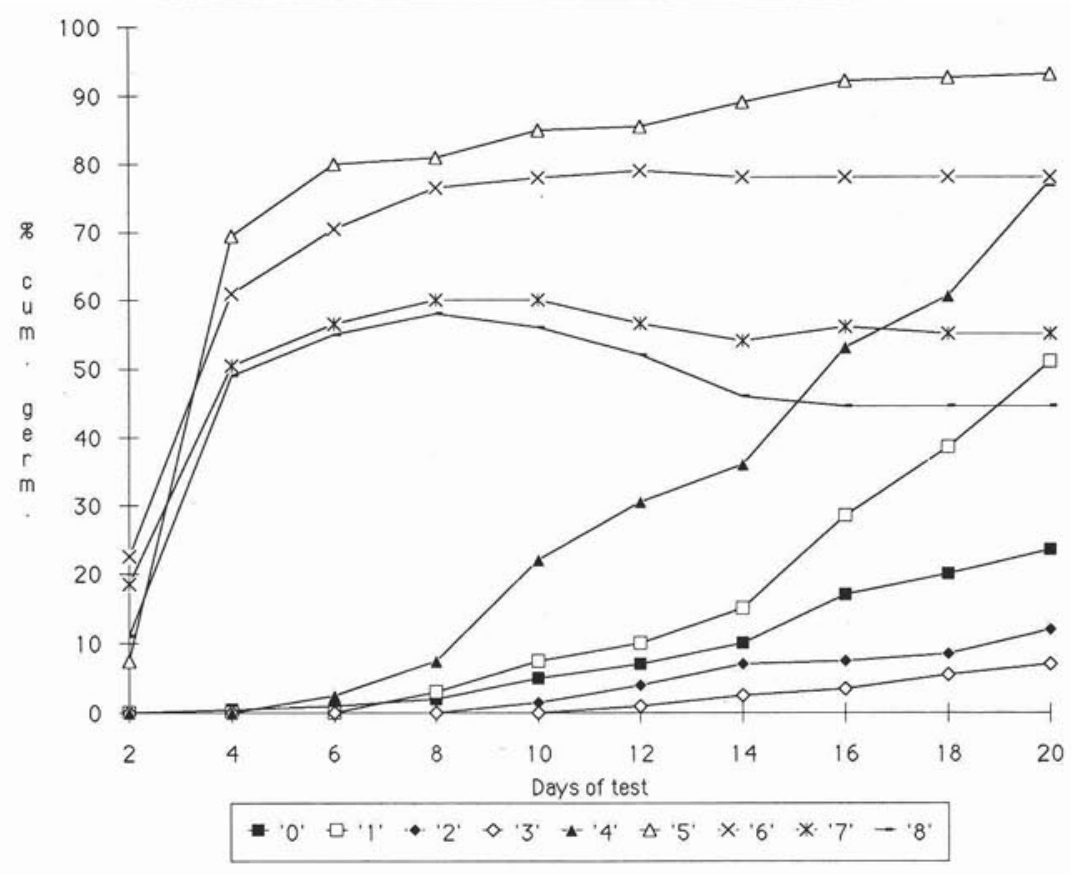

Figure 1. Germination of $R$. auriculiforme seeds after different treatments.

Table 3. Mean daily germination percentage of $R$. auriculiforme

\begin{tabular}{|c|c|c|c|c|c|c|c|c|c|c|}
\hline \multirow[b]{2}{*}{ Treatment } & \multicolumn{10}{|c|}{ Duration of germination test (days) } \\
\hline & 2 & 4 & 6 & 8 & 10 & 12 & 14 & 16 & 18 & 20 \\
\hline 0 & 0.00 & 0.01 & 0.17 & 0.25 & 0.50 & 0.58 & 0.71 & 1.06 & 1.11 & 1.18 \\
\hline 1 & 0.00 & 0.00 & 0.00 & 0.38 & 0.75 & 0.83 & 1.07 & 1.78 & 2.14 & 2.55 \\
\hline 2 & 0.00 & 0.00 & 0.00 & 0.00 & 0.15 & 0.33 & 0.50 & 0.47 & 0.47 & 0.60 \\
\hline 3 & 0.00 & 0.00 & 0.00 & 0.00 & 0.00 & 0.08 & 0.18 & 0.22 & 0.31 & 0.35 \\
\hline 4 & 0.00 & 0.01 & 0.42 & 0.94 & 2.20 & 2.54 & 2.57 & 3.31 & 3.36 & 3.88 \\
\hline 5 & 3.75 & 17.38 & 13.33 & 10.19 & 8.50 & 7.12 & 6.36 & 5.75 & 5.14 & 4.65 \\
\hline 6 & 11.25 & 15.25 & 11.75 & 9.56 & 7.80 & 6.58 & 5.57 & 4.88 & 4.33 & 3.90 \\
\hline 7 & 9.25 & 12.63 & 9.42 & 7.50 & 6.00 & 4.71 & 3.86 & 3.50 & 3.06 & 2.75 \\
\hline 8 & 5.50 & 12.25 & 9.17 & 7.25 & 5.60 & 4.33 & 3.29 & 2.78 & 2.47 & 2.23 \\
\hline
\end{tabular}

were the most consistent (Table 2). A comparison of mean daily germination revealed that treatment 5 gave the highest germination energy, with a peak value of 17.38 on the fourth day of the test (Table 3). The germination percentage at the time when the mean daily germination (cumulative germination divided by time elapsed since sowing date) reaches its maximum is referred to as the peak value (Czabator 1962) and has been renamed as the germination energy (Seward 1980). This Germination value is the only measure which attempts to forecast survival and mortality after the stage of germination but it is entirely dependent on the subjective choice of an appropriate criterion by which to define the energy period (Willan 1985).

Nicking Racosperma seeds has been reported to give the potential germination of a seed sample and is recommended for comparison when assessing the effect of other treatments and when sowing small and valuable research seedlots (Doran and Gunn 1987, Gunn 1990, Kobmoo et al. 1990). Manual nicking is not practical for nursery operations because large quantities of seeds are used by the growers. Mechanical scarification is an alternative but often gives erratic results (Gunn 1990), while acid scarification is a good method for managed large-scale plantations and for laboratory testing.
Water pretreatment (treatment 4 for these seedlots) is the most economical method for social forestry in rural communities. Treatment 4 was also the best for $R$. mangium (Willd.) Pedley, Comb. nov. (formerly A. mangium) from provenance Kinzono (KZNO) (Khasa, unpublished data). The results of the germination test conducted here under $30-20^{\circ} \mathrm{C}$ temperature regime (day-night) in Conviron G30 germinators are directly applicable to the nursery environment of the same temperature regime in Zaire and have been adopted by an industrial tree planting project and by local farmers.

It is important to determine for each species and each seedlot within a species, the best prescription that overcomes seed dormancy and ensures maximum nursery recovery of high quality seedlings. Most $R$. auriculiforme seeds are capable of germinating, without pretreatment, at the time of collection (Pukittayacamee and Hellum 1987), and seed dormancy increases when the seeds are dried for storage. Thus, pretreatment prescriptions need to be modified according to whether the seeds are freshly harvested or have been in storage.

\section{Acknowledgements}

This work was supported by a grant to the author from the Canadian International Development Agency (CIDA). 
I am grateful to Dr. T.J. Boyle (Petawawa National Foresty Institute, PNFI, Canada) for providing laboratory facilities, and to M.B. Downie for his valuable advice during this work and comments on the paper. I also wish to thank Ms. L. Clark for her technical assistance.

\section{References}

Anonymous. 1985. Étude de faisabilité concernant le reboisement du plateau des Bateke. Fonds Européen de Développement, Projet no 5.604.37.55.026 \& U.L.G. Consultant Ltd, Warwick, England. Cavanagh, T. 1987. Germination of hard-seeded species (order Fabales). Pages 58-70 In: P. Lanykamp (ed.). Germination of Australian native plant seed. Inkata Press, Melbourne, Australia. Czabator, F. J. 1962. Germination value: an index combining speed and completeness of pine seed germination. For. Sci. 8: 386-396.

Doran, J.C. and B.V. Gunn. 1987. Treatments to promote seed germination in Australian Acasias. Pages 57-63. In: J.W. Turnbell (ed.). Australian Acacias in developing countries: proceedings of an international workshop held at the Forestry Training Centre, Gympie, Qld., Australia, 4-7 August 1986, ACIAR proceedings No. 16.

Doran, J.C., J.W. Turnbell, D.J. Boland and B.V. Gunn. 1983. Handbook on seeds of dry-zone Acacias. FAO, Rome. pp. 59-63. Gunn, B.V. 1990. Germination pretreatments for selected Acacia species from the Pilbara Region of Western Australia. Pages 46-50 In: J.W. Turnbell (ed.). Tropical tree seed research: proceedings of an international workshop held at the Forestry Training Centre, Gympie, Qld., Australia, 21-24 August 1989. ACIAR proceedings No. 28.

International Seed Testing Association. 1985. International rules for seed testing, 1985. Seed Sci. Technol. 13: 300-513.
Jim, C.Y. 1990. Selection of tree species for urban plantatings in tropical cities. Pages 236-247. In: H. Oswald (ed.). IUFRO XIX World Congress, Montréal.

Kirk, R.E. 1982. Experimental design: procedures for the behavioral sciences. 2nd edition. Brooks/Cole Publishing Company. Kobmoo, B., O. Chaichanasuwat and P. Pukittayacamee. 1990. A preliminary study on pretreatment of seed of leguminous species. The Embryon 3: 6-10. Asean-Canada For. Tree Seed Centre, Thailand.

Marunda, C.T. 1990. Effects of seed pretreatments on the development of Acacia auriculiformis and A. holosericea seedlings. Pages 33-36 In: J.W. Turnbell (ed.). Tropical tree seed research: proceedings of an international workshop held at the Forestry Training Centre, Gympie, Qld., Australia, 21-29 August 1989. ACIAR proceedings No. 28.

Pukittayacamee, P. and A.K. Hellum. 1987. Seed germination in Acacia auriculiformis: developmental aspects. Can. J. Bot. 66: 388-393.

SAS Institute Inc. 1990. SAS ${ }^{\circledR}$ Procedures guide, Version 6, third edition. SAS Institute Inc., Cary, NC.

Seward, B.R.T. 1980. The production, handling and testing of forest tree seed in Zimbabwe - a review of methods and results. The Zimbabwe Bulletin of Forestry Research. 8: 19.

Turnbull, J.W. (ed.). 1986. Multipurpose Australian trees and shrubs. Aciar Monograph No. 1. ACIAR, Canberra, Australia. Wang, B.S.P. and F. Ackerman. 1983. A new germination box for tree seed testing. Petawawa National Forestry Institute, Forestry Canada. Inf. Rept. PI-X-27.

Willan, R. L. 1985. A guide to forest seed handling with special reference to the tropics. FAO Forestry Paper 20/2, Rome.

Zins, R. and K. Kambale. 1989. L'énergie-bois au Zaïre, bilan et perspectives. PAFT. Agence canadienne de développement international, Hull, Canada.

\section{Membership Dues 1992-1993}

\section{Active Membership}

1 st and 2nd year after graduation

(grad 1992, grad 1991) *(\$2.49 G.S.T. inc.)

$\$ 86.00$

Other new members for first year $*(\$ 2.49$ G.S.T. inc. $)$

Married or equivalent

second member only $*(\$ 2.49$ G.S.T. inc.)

All other active members $*(\$ 2.49$ G.S.T. inc.)

Other Memberships

Retired members (to qualify for retired status,

member must have 15 years membership in the

Institute $) *(\$ 2.49$ G.S.T. inc.)

Student Members *(\$1.31 G.S.T. inc.)

Sustaining Individuals (CIF/IFC Members)

Sustaining Corporate $*(\$ 4.98$ G.S.T. inc.)

Upon written application, spousal members of Active Members may have the dues of one reduced by an amount determined annually. Spousal members are members of the same Section who are living together as spouses and using the same mailing address.

The Institute year runs from July 1 to June 30. Applications dated after January 1, 1992 will be charged half dues for that Institute year. Applications dated after April 1st will be charged NO DUES for that Institute year.

Section dues are in addition and range from $\$ 5.00$ to $\$ 30.00$ per Institute year.

*Note: The portion of membership which covers the cost of the Forestry Chronicle is subject to G.S.T. For tax purposes, this cost is calculated on $\$ 38.00$ which is $\$ 2.49$ G.S.T. (except Student rate of $\$ 20.00 @ \$ 1.31$ G.S.T.) 